\title{
A WOODLAND SYMPHONY
}

By LINDA EDWARDS, age 13, Bladworth, Saskatchewan

reen mansions cif majestic trees

iltering the sun to fall

$n$ quiet contentment

on a sleeping fawn.

11 is so peaceful and quiet

hat you verily seem to be

n a cathedral,

But were not woods like these

fod's first temples?

he white-throated sparrow's song is

ot like a break in the silence

sut like a hymn blending in.

zephyr gently blows from a hidden vale

Bringing the faint but lingering scent of violets

fo blend with that of spruce and pine.

Near a mossy old log reclining in the sun

peceitfully be a u t if u l mushrooms grow,

Brilliant oranges, reds and yellows

Some paling with age.

Now dim mysterious isles of pines and firs

Give way to a more open stance

Where white birches, like graceful maidens swaying in the breeze,

And whispering pretty secrets to the bubbling brook

And where the soft-eyed doe doth drink,

Ever watchful-

A calm and mystic woodland pool, Cut by a leaping fish

That dives to under-water caverns, And in his wake

A cool spray of water dampens green arpets of velvet moss.

A water spider scurries by

And leaves the pool frowning as though angered
At the impudence of this tiny creature.

A duck glides silently beneath the overhanging willow

Who balances as a dainty lady on tip

tces to better see

The everchanging patterns cast on

the water, through the aspens.

And in the evening

Twilight creeps gently in

Covering all with his dusky mantle, And through the pines

The evening sunset sheds

Its soft light on a hermit thrush

Pouring forth silver chords of sound

So wondrous that it cannot seem to

be a mere bird's song

But that of angels.

A grouse drums forth his song of love And challenge,

While from the lake

A loon sends forth its awesome cry

To echo and re-echo

As the silver keeper of the night

Slips above the pines

And spreads its tranquil radiance over all.

A spider spins her silken web

Unmindful of the exquisite, velvetwinged moths that flutter by

Till the magic silver light of dawn

Awakens the thrush

And the warbler and the lark

To join in one spiraling song of joy

While the water-lily unfolds her petals

And the butterfly spreads his wings And the flowers all lift their dewstudded heads

And it seems all the world joins in and sings

This glorious movement of the never :easing and never the, same

Woodland Symphony.

\section{Spider Eggs}

by Sam Beckie, age 11, Bladworth, Sask.

One day while playing ball I lifted up the first base and found under it a curious thing. There was a little tube made of grass, about an inch deep, and at the bottom was a spider, with what looked like a very small golf ball fastened to its stomach.

We took it into the school to in- spect it under the magnifying glass. We split the sack and inside were tiny eggs. We later found in our reference books that there were only a few spiders like this. We found that certain spiders spin silken sacks in which they carry their eggs until they can shift for themselves.

We are not definite yet what kind of spider we found. Both the Hunting and Wolfe spiders carry their eggs in this manner. 